\title{
Monitoring udder health and milk quality using somatic cell counts
}

\author{
Ynte H. SCHUKKEN*, David J. WILSON, Francis WelCOME, \\ Linda GARRISON-TIKOFSKY, Ruben N. GONZALEZ \\ Quality Milk Production Services, Cornell Veterinary Medicine, Cornell University, \\ 22 Thornwood Drive, Ithaca, NY, 14850, USA
}

(Received 7 January 2003, accepted 12 June 2003)

\begin{abstract}
In this article the use of somatic cell counts for monitoring udder health and milk quality is discussed. Somatic cell count dynamics at quarter, cow, herd and population level are discussed and illustrated with examples. Quarter and cow somatic cell counts directly represent the inflammatory status of the mammary gland. Herd and population somatic cell count are related to the inflammatory process in individual cows but much more reflect the udder health status of the herd and the quality of the raw milk in the herd and the population. Application of monitoring tools in herd health management are illustrated using a case study. Understanding infection dynamics requires precise longitudinal data. Monitoring tools are required to find the areas of risk in the herd. It is inevitable that more complete udder health programs and monitoring systems are to be developed and implemented. These programs are necessarily dynamic and complex. Implementation of complete udder health programs should be accompanied by research efforts to further fine-tune these complete udder health control and monitoring programs.
\end{abstract}

somatic cell count / mastitis / milk quality / monitoring / epidemiology

\section{Table of contents}

1. Introduction

2. Somatic cell count patterns during the inflammatory process ...................................................... 580

2.1. Somatic cell count patterns at quarter level ....................................................................... 580

2.2. Somatic cell count patterns at cow level ........................................................................... 582

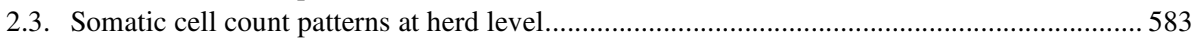

2.4. Somatic cell count patterns at population level............................................................ 584

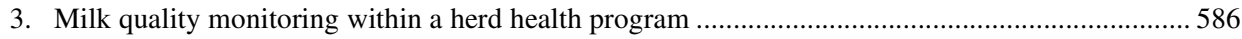

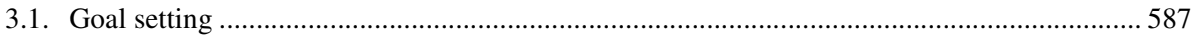

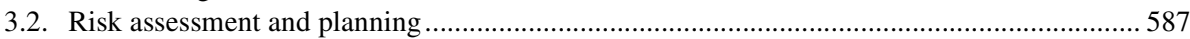

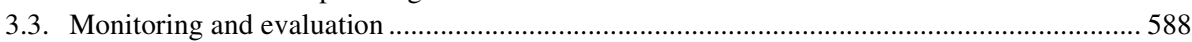

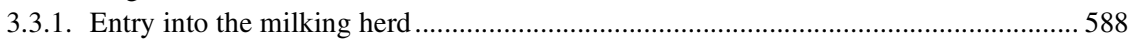

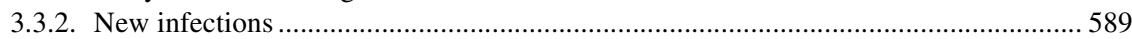

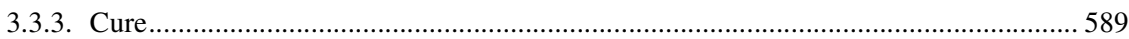

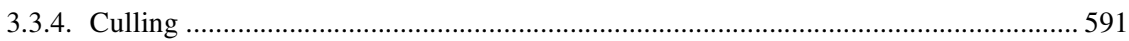

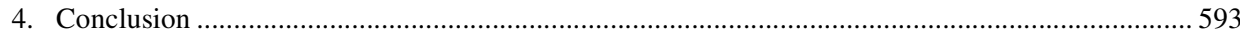

\footnotetext{
* Corresponding author: yhs2@ cornell.edu
} 


\section{INTRODUCTION}

Throughout the world, the importance of udder health programs has increased in the last ten years [16, 34, 39, 40, 45]. There are a number of reasons for this awareness of udder health as a critical production issue on dairy farms. In Europe, the EEC directive 92/46 in April 1992 stated that milk with a somatic cell count (SCC) over 400000 cells per $\mathrm{mL}$ may not be used for fluid milk and starting in 1998 not even for human consumption. In North America limits at 750000 (USA) and 500000 cells (Canada) are in place [45]. Another issue is the increased awareness of consumer and dairy organizations with regard to animal welfare issues. Clinical mastitis may be a severe and painful disease that causes distress to the animal. It is therefore important to decrease the clinical incidence of disease. A third, more recent issue are human health concerns regarding milk consumption. This includes antibiotic residues in milk, transfer of antibiotic resistance from animal to human, and transfer of pathogens or products thereof through milk or milk products $[30,39,40,60]$. Approximately $80 \%$ of antibiotic residues in milk can be traced back to mastitis treatments, either during lactation or during the dry period [27, 43]. Hence, monitoring programs will need to address these three components. Their ultimate goal is to aid the producer in herd management and to guarantee the quality of the raw product to the consumer [6].

The objective of this review is to summarize the widely available tools for evaluating udder health and milk quality on dairy farms. First, the inflammatory process in the mammary gland will be observed at quarter, cow, herd and population level (see also [37]). Thereafter monitoring available to the dairy producer in a veterinary herd health program will be summarized. Monitoring the inflammatory process in the mammary gland can be done using several diagnostic tools including but not limited to somatic cell counts, conductivity, California mastitis tests (CMT) [46],
$\mathrm{N}$-acetyl- $\beta$-D-glucosaminidase (NAGase) and many others [42] for a review of diagnostic tests. In this review somatic cell count will be emphasized because of their use in regulatory systems and wide availability and use throughout the dairy industry in the world.

\section{SOMATIC CELL COUNT PATTERNS DURING THE INFLAMMATORY PROCESS}

\subsection{Somatic cell count patterns at quarter level}

Somatic cells are mostly cells of the immune system $(80 \%$ in uninfected quarters, $99 \%$ in mastitic quarters) [54]. These somatic cells are part of the natural defense mechanism and include lymphocytes, macrophages, polymorphonuclear cells and some epithelial cells [38]. Somatic cells are therefore a reflection of the inflammatory response to an intramammary infection or another trigger of the immune system. Somatic cell count, or a parameter derived from this count, is often used to distinguish between infected and uninfected quarters. There is a general agreement between infection status and the inflammatory response to this infection as measured by an increased SCC. As with any diagnostic test, errors will occur when solely depending on a single test. To minimize the amount of error, diagnostic test parameters such as sensitivity and specificity are calculated at various cut-off values in the SCC continuum [47]. Research from North America and Europe has shown that uninfected quarters have a mean SCC of approximately 70000 cells $[10,11,27,47]$. There is of course variation around this mean, and it was also shown that the mean SCC of uninfected quarters increases with age, decreasing milk production and days in milk [47]. Hence, to be able to distinguish between infected and uninfected quarters it was repeatedly shown that a cut-off of approximately 200000 to 250000 cells was 
optimal to reduce diagnostic error [11, 24, $27,47]$. At this cut-off value, diagnostic sensitivity was shown to be approximately $75 \%$, while specificity was approximately $90 \%$ [47]. Throughout this paper a cut-off of 200000 cells $/ \mathrm{mL}$ will be used. The 200000 cut-off is not considered a physiological cell concentration in milk distinguishing "healthy" from unhealthy quarters or udders, but that it is an operational threshold of practical value under field conditions (minimizing diagnostic error), not the ultimate goal for udder health and production of the best quality milk. Other thresholds (such as 100000 or 500000 ) are advocated by others. Any threshold of cell counts to indicate intramammary infection will have its advantages and disadvantages, we have selected 200000 to minimize classification error. A parameter based on somatic cell count that is often used is the Linear Score (LS). The LS is a base 2 logarithmic conversion of SCC [50]. Cow LS is calculated as $\mathrm{LS}=\log _{2}(\mathrm{SCC} / 100)+3$, where SCC is cells $/ \mu \mathrm{L}$. The conversion of LS to $\mathrm{SCC}$ is calculated as $\mathrm{SCC}=100 \times 2^{(\mathrm{LS}-3)}$.

When a cow gets infected, the resident somatic cells signal to a resting population of white blood cells in the blood stream, and a massive influx of mostly polymorphonuclear cells into the milk takes places $[8,51]$. These cells kill bacteria, and when the infection is eliminated then usually within a few weeks cell count of milk returns to normal. An example of such a response is presented in Figure 1A, where data are presented of an experimental E. coli infection. The intramammary infection with $E$. coli was eliminated in approximately two days [58].

When the immune system is not able to remove the bacteria, a chronic infection within the mammary gland results in a continuous trigger and somatic cell counts are high long term [18]. This process is depicted in Figure 1B, where somatic cell counts in a chronic E. coli infection is shown [12]. Usually, there is fluctuation in cell counts, but cell counts are often above the previously defined cut-off for uninfected quarters. Based on these infection dynamics phenomena, somatic cell counts are particularly useful to follow individual quarters or cows over time. Only quarters and cows with long term high cell counts are indicators of chronic infection in these animals and require further management attention. Short term high counts are not
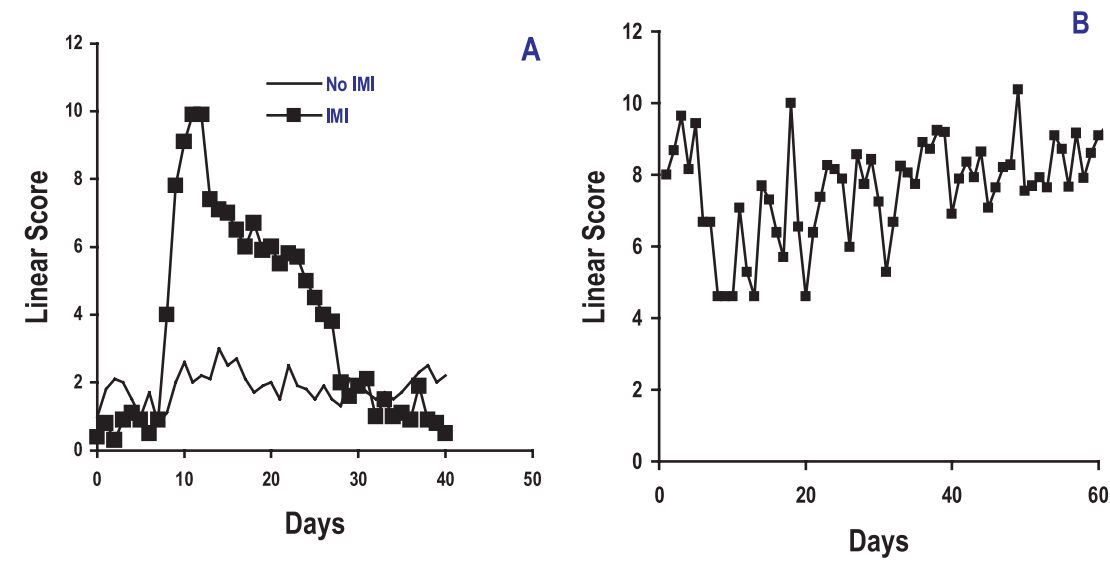

Figure 1. A: Somatic cell count pattern during a successful immune response to an incoming $E$. coli bacterial infection. A non-infected contra lateral quarter is shown to represent non-infected quarters (data from [58]). B: Somatic cell count pattern of a quarter chronically infected with E. coli (data from [12]). 
necessarily a reason for concern since an apparent immediate cure occurred. Clearly, SCC data are used as a proxy for infection. In some situations quarters with low SCC may still harbor infection (see for example $[7,12,18])$. Only with repeated bacteriological culture an accurate diagnosis of cure of IMI can be made.

\subsection{Somatic cell count patterns at cow level}

Somatic cell counts are usually measured in composite cow milk. It is particularly important to characterize the relationship between presence of an intramammary infection (IMI) with the cell count response of the cow in the composite milk. Knowledge of this relationship will enable inferences about IMI prevalence, from somatic cell count data, which is routinely recorded in $91 \%$ of herds that are participating in milk recording in the United States of America [35]. The most accurate relationship between IMI and SCC exists at quarter level. Cow composite samples of SCC and IMI are a composite of four quarters with dependent but separate infection status and inflammatory response. Most dairy producers and dairy veterinarians have only access to cow composite information and therefore the relationship between these two parameters is of great practical importance. There are essentially two approaches to relating cow-SCC and IMI. First, known infected or non-infected cows can be followed, and the mean cell count for these two groups of cows can be calculated, or diagnostic parameters such as sensitivity and specificity can be obtained [24, 28]. Second, cows can be classified based on their cell count level and the probability of IMI can be calculated. An example of this second approach will be presented in some more detail. Here, the AVELS was the Average of Monthly Linear Scores in the current lactation up until the time of bacteriological culture (an average of 150 days in milk). The AVELS was available for 65229 cows whose composite milk was cultured for bacteriologic diagnosis of IMI at 914 herd visits from March, 1992 to April, 2000 in New York State. Sampling methodology and bacteriology were described in detail by [61]. Association between AVELS category $(0.1-0.9 ; 1.0$ $1.9 ; 2.0-2.9$, etc. to 9.0-9.9) and whether cows within each score had IMI defined by positive milk culture (also a categorical variable) were evaluated using Chi-square. Table I shows the prevalence of IMI within each one-log interval of AVELS for major pathogens (Streptococcus agalactiae, Staphylococcus aureus, environmental streptococci, and Mycoplasma spp.), other major pathogens (Escherichia coli, Klebsiella, Serratia, Arcanobacter pyogenes) and minor mastitis pathogens (Corynebacterium bovis, coagulase negative staphylococci (CNS)). For all types of IMI, cows with AVELS < 3.0 had significantly less IMI than the overall population mean. Those with AVELS $\geq$ 4.0 and for each higher log category of AVELS up through $\geq 9.0$ had higher prevalence of major pathogens (chi-square, $P<$ 0.001, Tab. I). Minor pathogens were significantly less present in AVELS $<2.0$ and in AVELS > 6.0, and showed a higher prevalence between AVELS from 2.0 to 5.9.

Results demonstrated that AVELS was a good indicator of IMI prevalence in this dairy cow population. The strongest increases in IMI prevalence occurred with increases in AVELS between 2.0 and 5.9. Within this range, prevalence of all pathogens (major and minor) increased by on average $12 \%$ for each one-point increase in AVELS. From the standpoint of improved management, total IMI prevalence would be expected to decrease by $12 \%$ for each one-point drop in AVELS within the above range.

Mean AVELS for cows without IMI was just below 3.0, corresponding to a geometric average SCC of 96000 cells $/ \mathrm{mL}$. This is higher than the average SCC reported in another study [24] of cows that were repeatedly and consistently cultured negative for IMI each month during lactation, which was approximately 50000 cells $/ \mathrm{mL}$. For 
Table I. Prevalence of mastitis pathogens among cows in each Average lactation Linear Score (AVELS) category.

\begin{tabular}{|c|c|c|c|c|c|c|c|c|c|c|c|}
\hline AVELS & Total & Negative & $\%$ & $\begin{array}{c}\text { Major } \\
\text { pathogens }\end{array}$ & $\%$ & $\begin{array}{l}\text { Other major } \\
\text { pathogens }\end{array}$ & $\%$ & $\begin{array}{c}\text { Minor } \\
\text { pathogens }\end{array}$ & $\%$ & Other & $\%$ \\
\hline $0.1-0.9$ & 2643 & 2237 & $85 \uparrow$ & 110 & $4 \downarrow$ & 12 & $0^{\downarrow}$ & 231 & $9^{\downarrow}$ & 53 & $2^{\downarrow}$ \\
\hline $1.0-1.9$ & 11245 & 9029 & $80 \uparrow$ & 484 & $4^{\Downarrow}$ & 66 & $1^{\Downarrow}$ & 1413 & $13^{\downarrow}$ & 253 & $2^{\downarrow}$ \\
\hline $2.0-2.9$ & 14727 & 9736 & $66 \uparrow$ & 1156 & $8^{\Downarrow}$ & 93 & $1^{\Downarrow}$ & 3413 & $23 \uparrow$ & 329 & $2^{\Downarrow}$ \\
\hline $3.0-3.9$ & 12609 & 6465 & $51^{\Downarrow}$ & 1998 & $16^{\downarrow}$ & 122 & $1^{\Downarrow}$ & 3698 & $29 \uparrow$ & 326 & $3^{\downarrow}$ \\
\hline $4.0-4.9$ & 9661 & 3939 & $41^{\Downarrow}$ & 2772 & $29 \uparrow$ & 162 & $2^{\Downarrow}$ & 2457 & $25 \uparrow$ & 331 & $3 \uparrow$ \\
\hline $5.0-5.9$ & 7226 & 2307 & $32^{\downarrow}$ & 2850 & $39 \uparrow$ & 136 & $2 \uparrow$ & 1651 & $23 \uparrow$ & 282 & $4 \uparrow$ \\
\hline $6.0-6.9$ & 4431 & 1186 & $27^{\Downarrow}$ & 2042 & $46 \uparrow$ & 134 & $3 \uparrow$ & 867 & $20 \downarrow$ & 202 & $5 \uparrow$ \\
\hline 7.0-7.9 & 1946 & 456 & $23^{\downarrow}$ & 989 & $51 \uparrow$ & 70 & $4 \uparrow$ & 323 & $17 \downarrow$ & 108 & $6 \uparrow$ \\
\hline $8.0-8.9$ & 592 & 146 & $25^{\downarrow}$ & 294 & $50 \uparrow$ & 34 & $6 \uparrow$ & 87 & $15^{\downarrow}$ & 31 & $5 \uparrow$ \\
\hline 9.0-9.9 & 148 & 39 & $26^{\downarrow}$ & 64 & $43 \uparrow$ & 13 & $9 \uparrow$ & 21 & 14 & 11 & $7 \uparrow$ \\
\hline Total & 65228 & 35540 & $54^{\Downarrow}$ & 12759 & 20 & 842 & 1 & 14161 & 22 & 1926 & 3 \\
\hline
\end{tabular}

$\uparrow$ Significantly more than expected, $P<0.05 ; \downarrow$ Significantly less than expected, $P<0.05$.

${ }^{a}$ Major pathogens are $S$. agalactiae, $S$. aureus, environmental streptococci, and Mycoplasma, other major pathogens are E. coli, Klebsiella, Serratia, A. pyogenes, minor mastitis pathogens are C. bovis, and CNS.

the sum of all the difference in prevalence between the lowest AVELS category ( 0.1 to $0.9)$ and the second lowest category (1.0 to 1.9) was small. However, for cows with AVELS between 2.0 and 2.9, prevalence for all pathogens was $34 \%$, substantially above the prevalence of $20 \%$ for AVELS between 1.0 and 1.9. Most of the IMI at these low AVELS ranges was due to CNS and $C$. bovis; their prevalence decreased steadily among cows with AVELS > 4.0. This agrees with previous reports that CNS and $C$. bovis have a relative small effect on increasing SCC [10, 22, 25, 31, 61]. These facts suggest that a goal for AVELS should be around 2.0 (50000 cells $/ \mathrm{mL})$ to attain the lowest practical level of IMI. Little benefit would be gained by striving for AVELS below 2.0. More than $20 \%$ of the cows in this study were below AVELS 2.0. Striving for cell counts below this level has been reported to lead an increased risk of clinical mastitis [3, 17, 55], although this is still somewhat controversial [44].

\subsection{Somatic cell count patterns at herd level}

Monitoring somatic cell counts at herd level requires longitudinal data over time. Given the variability in inflammatory responses between all cows that make up a herd. An average bulk milk SCC of 50000 cells $/ \mathrm{mL}$ is therefore not a realistic goal [23, 33]. Prevalence of infection increases with mean bulk milk SCC but this is not tight relationship due to the lognormal nature of cow SCC. At herd level it is especially important to follow trends over time, and interfere when the cell counts appear to increase above a given threshold. In Figure 2, cell counts of a herd are shown during approximately three years. Mean bulk milk SCC in this herd is approximately 200000 cells $/ \mathrm{mL}$, with a standard deviation of approximately 35000 cells $/ \mathrm{mL}$. Using process control algorithms, 95\% confidence limits around a given mean can be calculated [41]. Observations outside these intervals would represent true deviations of 


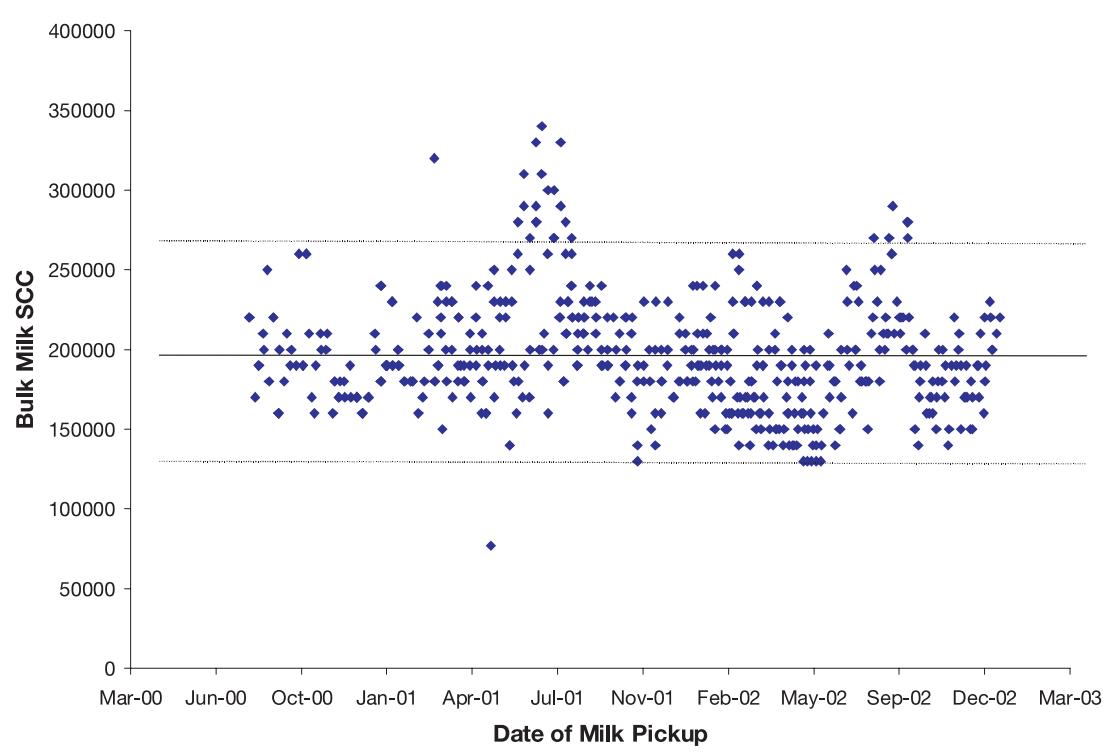

Figure 2. Longitudinal bulk milk SCC data for a dairy farm. In the graph the mean bulk milk SCC is indicated with a solid line, $95 \%$ confidence limits calculated using process control algorithms are indicated in dotted lines.

the udder health situation. In this example (Fig. 2) such deviations from acceptable are observed in May-June 2001, and in August-September 2002. During these periods, a further investigation into the reasons for this increase in bulk milk SCC is warranted (see further).

However, udder health and milk quality is defined by more parameters then prevalence of subclinical mastitis or SCC. Clinical mastitis is in herds an equally important issue. Recently, Elbers and co-workers reported an increase in herd level incidence of clinical mastitis with a decreasing bulk milk SCC [13, 29]. Barkema [1, 2] also reported a slight but non-significant increase in clinical mastitis in herds with a low bulk milk SCC (Fig. 3), but they observed a greater proportion of clinical cases with systemic signs of illness in herds with a low bulk milk SCC compared to herds with a higher bulk milk SCC [2]. Average rate of clinical cases in the latter (Dutch) study was 26 cases per 100 cowyear at risk. Clinical mastitis incidence rates have increased in Denmark in the last four years (from 29\% to 39\%), decreased in Finland (from $32 \%$ to $23 \%$ ) and approximately level in Norway (45\%) and Sweden $(21 \%)$ [34]. Clearly, a decrease in prevalence of subclinical mastitis has not resulted in an associated decrease in clinical mastitis [14, 20].

\subsection{Somatic cell count patterns at population level}

Since the introduction of a standard mastitis prevention program by Neave [32], an enormous progress in decreasing the prevalence of infection, and in decreasing average bulk milk somatic cell count (BMSCC) in national milk production has been achieved. As an illustrative example Honkanen-Buzalsky and Myllys [22] and Myllys et al. [31] reported the prevalence of intra mammary infections in Finnish cattle in both 1988 and 1995. An important decrease in prevalence was seen with S. agalactiae (from $0.78 \%$ to $0.12 \%$ ), S. dysgalactiae (0.79 to 0.08$), S$. uberis 


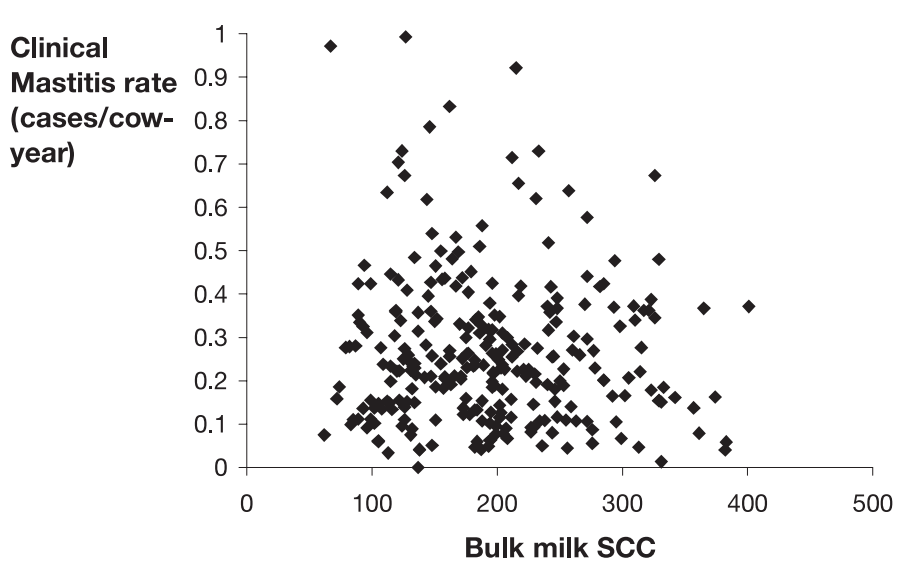

Figure 3. Relationship between bulk milk SCC $(* 1000)$ and incidence rate of clinical mastitis in cases per cow-year (data from [1]).

(1.18 to 0.72 ), and S. aureus (5.12 to 3.50 ). A slight increase was observed in coliforms (0.26 to 0.29 ). Similarly, minor pathogens such as CNS (6.57 to 11.24) and coryneforms (0.82 to 3.49$)$ have also increased in prevalence. During these years an associated decrease in bulk milk SCC was also observed: from 330000 in 1988 to 170000 cells $/ \mathrm{mL}$ in 1995 . In other countries in the same period a decrease in bulk milk SCC was also observed $[35,39,40$, 46]. Apparently, the standard mastitis prevention program has indeed been successful to reduce the prevalence of infections. Monitoring milk quality over time provides an opportunity to evaluate progress, study relationships between milk quality parameters and estimate the efficacy of control programs [5, 45, 49].

The monitoring data that is summarized here was obtained from five of the largest milk plants operating in New York State (Agri-Mark, Allied Federated Cooperatives Inc., Dairylea Cooperatives Inc., Dairy Farmers of America, Upstate Farms Cooperatives) [57]. Data included monthly milk loads (in $\mathrm{kg}$ ) and test results for SCC, bacteria count (reported as Plate Loop Count, PLC), antibiotic residue violations, freezing point, butter fat, protein and lac- tose. In this study, only milk loads, SCC, PLC and antibiotic residue violations were used. To analyze consequences related to farm size (milk load), farms were classified into milk load categories month by month, according to quartiles of total observations. Q1 included farms with $\leq 23000 \mathrm{~kg}$ in a specific month, Q2 had farms with $23000<\mathrm{kg} \leq 34000$, Q3 had farms with $34000<\mathrm{kg} \leq 68000$, and Q4 had farms with milk loads $>68000 \mathrm{~kg}$ in a specific month. To evaluate the contribution of an individual farm to overall SCC in the milk pool, a new parameters, termed SCC contribution was calculated for each farm in each month SCC contribution was determined as the excess SCC over the previously defined cut-off level of 200000 . SCC contribution was calculated for a particular farm in a particular month weighted by the amount of milk the farm produced that month out of the total amount of milk in the milk pool that month [49].

The average weighted SCC (weights according to amount of milk sold) was $308 \times 10^{3}$ cells $/ \mathrm{mL}$, the average PLC amounted $24.4 \times 10^{3}$ bacteria $/ \mathrm{mL}$, and the average number of antibiotic residue violations in the pool of milk was 3.9 per 1000 producers. Each month between $72 \%$ 


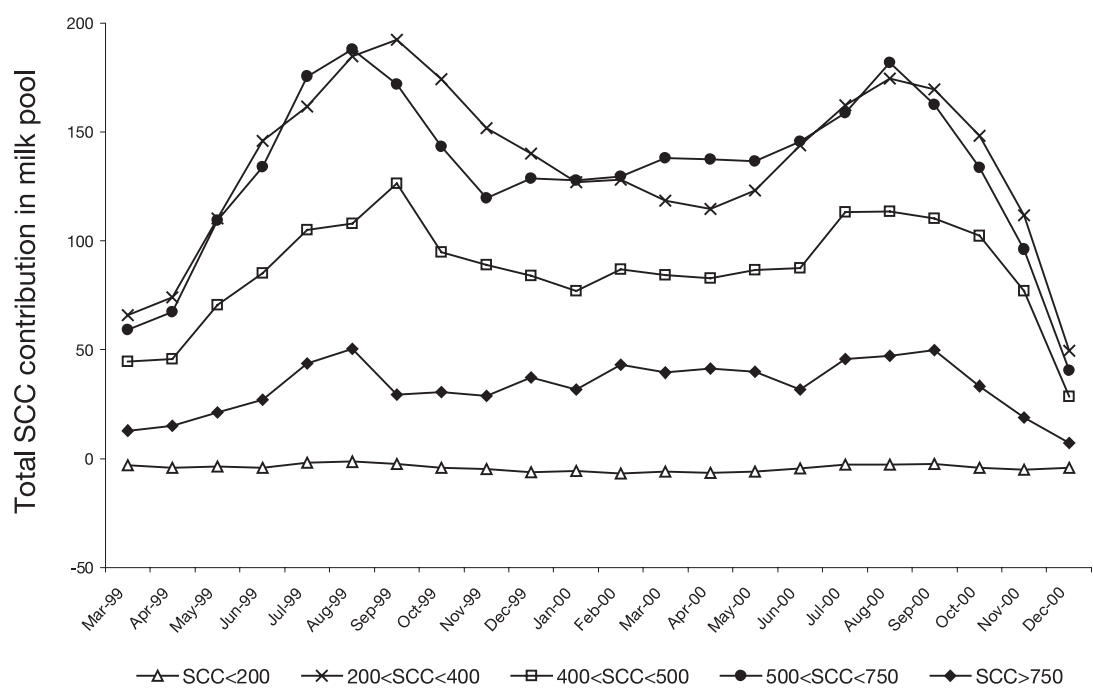

Figure 4. Total SCC contribution to the milk pool of farms classified according to their bulk milk SCC level.

and $88 \%$ of the milk pool had SCC levels in compliance with the EU requirements $\left(\mathrm{SCC}<400 \times 10^{3}\right.$ cells $\left./ \mathrm{mL}\right)$. Larger farms had lower SCC and PLC but more antibiotic violations. However, the larger farms contribute most to the SCC of the total pool of milk. Farms with high SCC also had higher PLC and more antibiotic violations but contributed as a group relatively few somatic cells to the milk pool (Fig. 4). As shown in Figure 4, the group of farms with moderately elevated SCC $\left(200-400 \times 10^{3}\right)$ or more elevated but still legal (in USA) cell counts $\left(500-750 \times 10^{3}\right)$ contribute most to the overall SCC in the pool of milk in New York State. SCC contribution reflects both SCC levels and the size of the farms ( $\mathrm{kg}$ of milk sold per month). Total SCC contribution per category reflects, in addition, the number of farms in that category. Hence the highest SCC contributions come from farms that are not necessarily in the highest SCC level category. Farms in the $200<\mathrm{SCC}<400$ and $500<\mathrm{SCC}<$ 750 categories contribute most to the SCC level in the milk of NYS. Figure 5 shows that farms with SCC levels below $200 \times$ $10^{3}$ cells $/ \mathrm{mL}$ had low PLC levels (equal or less than $25 \times 10^{3}$ bacteria $/ \mathrm{mL}$ ). Furthermore, farms with high SCC levels more often had high PLC levels. This finding may imply that subclinical mastitis cases cause an increase in bulk milk bacteria count [19]. However, herds with subclinical mastitis may also have problems in the area of general hygiene and milking equipment cleaning and disinfection $[1,2]$.

Farms with higher SCC levels (SCC > 750) showed a much higher rate of antibiotic residue violations. Furthermore, larger farms exhibit a higher rate of antibiotic residue violations (Fig. 6).

\section{MILK QUALITY MONITORING WITHIN A HERD HEALTH PROGRAM}

The general process of herd health management is depicted in Figure 7. First, the goals of the producer are identified. Based on these goals, the current practices are 


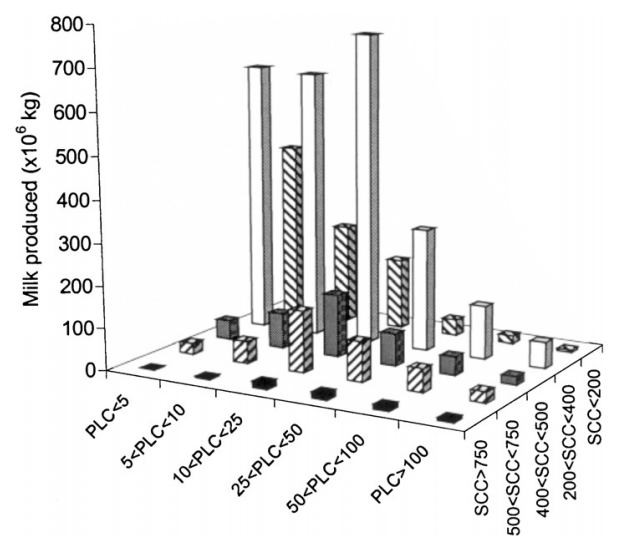

Figure 5. Total milk produced cross-classified by PLC category and SCC category.

evaluated, and the risk profile in the herd is identified. The goals and the current risk profile are used by the veterinarian to identify the most obvious gaps in current management of the farm operation [1, 2, 9, 61]. These gaps are discussed with the producer, and improvements are planned. For each of the planned tasks, the procedures are discussed, and the responsible person is identified. New procedures are implemented, and implementation is documented on the farm. On a regular basis the results are monitored and evaluated, and when things go according to plan, the goals can be further discussed, and continuous improvement is possible. Each of these components will be discussed in somewhat more detail, with a special emphasis on monitoring and evaluation processes.

\subsection{Goal setting}

This could be a bulk milk somatic cell count below 200000 with a mastitis incidence of less than $20 \%$. To be able to evaluate true deviations from proposed goals, an estimate of "normal" variability around the goal should also be calculated. Usually, variability in mean SCC increases with the mean SCC, and variability decreases with herd size. Formal quality control procedures can be defined to identify abnormal SCC performance [59]. The goals should be defined in a collaboration between the dairy producer and the herd health veterinarian. Realistic goals are important, when goals are beyond reach, this could actually lead to a loss of motivation for the producer and the employees.

\subsection{Risk assessment and planning}

When thinking about Risk assessment it is probably essential to keep the biology of udder health dynamics as a central focus. In Figure 8, the dynamics of infection in herds is depicted. The key components in this figure are the rate of new infections,
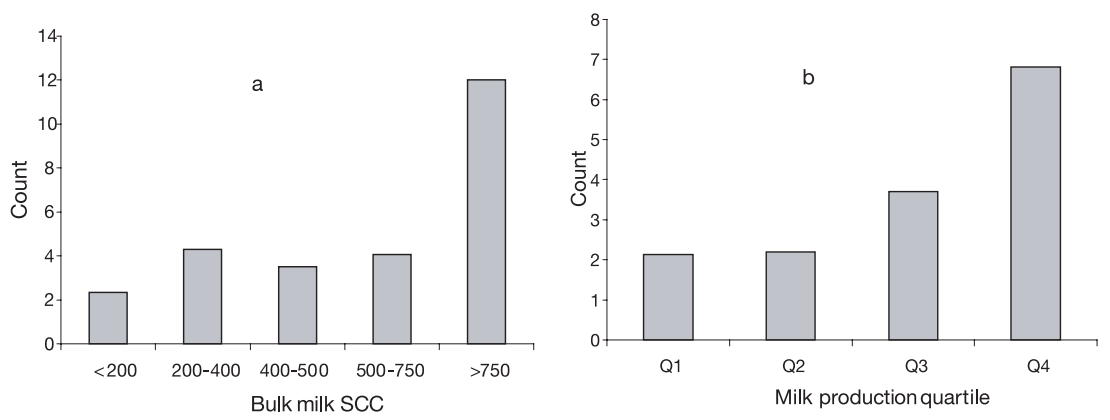

Figure 6. Antibiotic residue violations per 1000 producers by SCC category (a) and by milk production quartile (b) (adapted from [57]). 


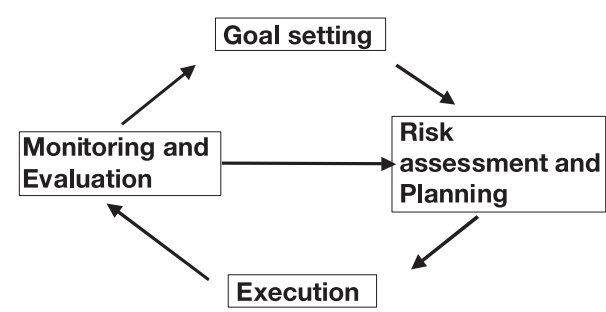

Figure 7. The general principle of herd health programs.

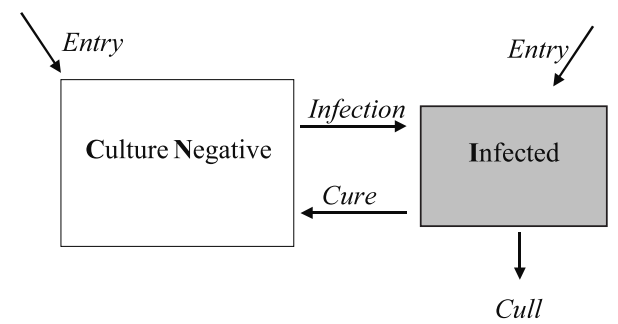

Figure 8. Dynamics of intra mammary infections in a dairy herd.

the cure rate, the culling rate, and the entry of infected or non-infected animals into the milking herd [4]. For each of these components of the herd infection dynamics a number of specific risk factors are known $[13,15,48,61]$.

\subsection{Monitoring and evaluation}

Monitoring and evaluation of the current performance should include analysis of data from the herd, evaluation of farm management and housing through observation, and the observation of clinical data from animals in the herd. For each of the components of udder health dynamics as presented in Figure 8 a number of parameters for monitoring and evaluation are presented.

\subsubsection{Entry into the milking herd}

Evaluation of culture results from cows purchased into the herd is the preferred option for monitoring the entry of clean animals into the herds. A similar monitoring system should be implemented for incoming heifers. As an alternative (albeit less accurate) the evaluation of cell count data in the first milking after calving can be used to evaluate the udder health status of incoming animals. A goal could be to have less than $10 \%$ of incoming heifers with a cell count over 200000 to 250000 cells per mL. In the herd depicted in Figure 9, the percentage of infected heifers is much too high (approximately 20\%). Monitoring of housing quality and hygiene levels for

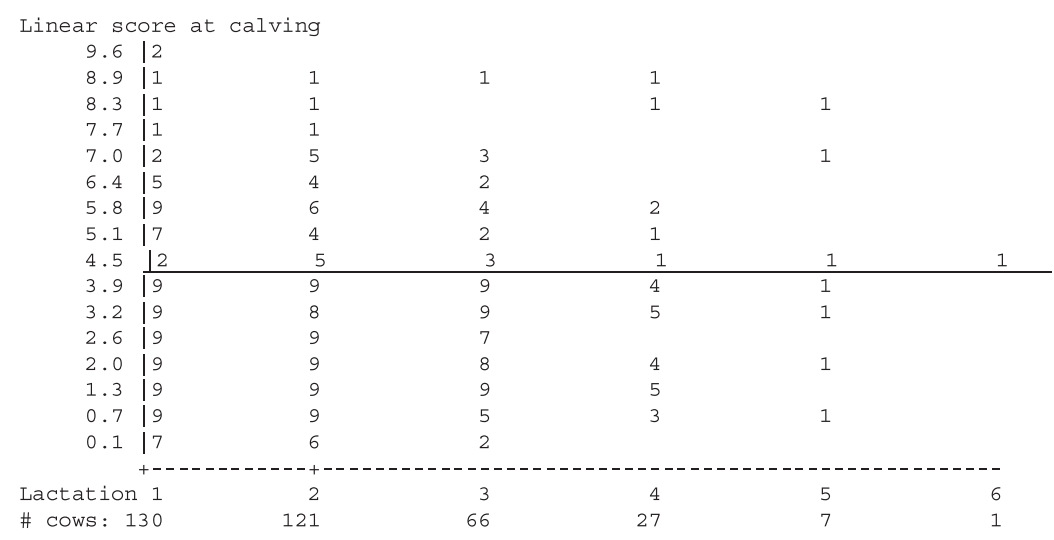

Figure 9. Linear score at calving for cows in lactation number 1 to 6 . The numbers in the graph reflect the number of animals in each lactation at each LS level. 


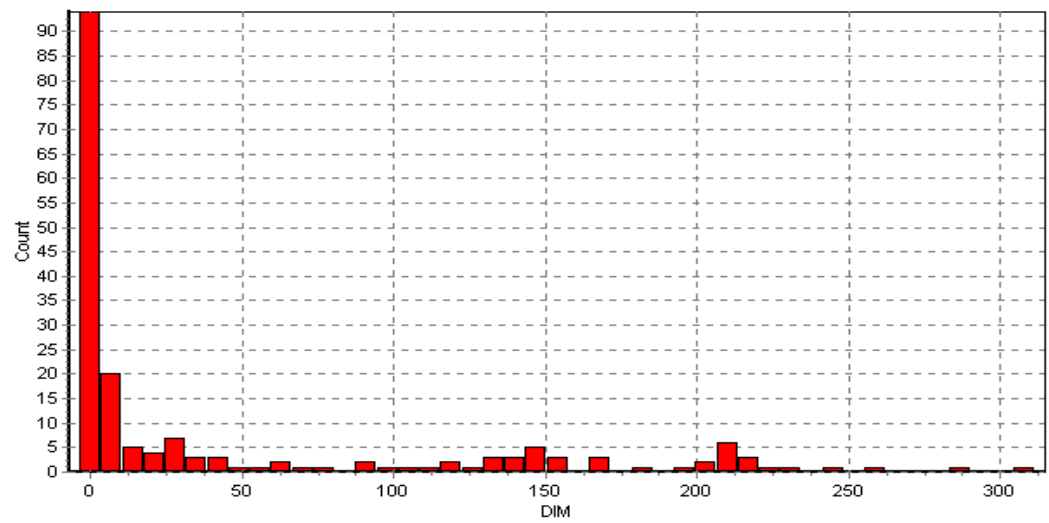

Figure 10. Clinical cases graphed against days in milk (DIM) at occurrence of the clinical case.

heifers and dry cows is then an important tool in further analysis of the udder health problems in this herd [36].

\subsubsection{New infections}

Recording and sampling of clinical mastitis cases is important to obtain data on new clinical infections. Clinical mastitis data can be summarized as the number of cows with at least one clinical case per lactation, or alternatively can be graphed against days in milk at the occurrence of clinical case (Fig. 10).

For subclinical infections, repeated bacteriological culture of all quarters of all cows in the herd provides excellent data for research in infection dynamics monitoring $[4,26]$ but is clearly not practical for commercial herds. Repeated cell counting of animals is a relative cheap and more practical method to obtain information on new infections. The proportion of low SCC animals that has a SCC over 250000 in the next measurement is a key proxy monitoring tool for subclinical infections [47]. This proportion should generally be less than $10 \%$. In Figure 11, the linear score in the last test day (LS) is graphed against the linear score in the previous test day (PLS). A linear score of 4.5 is equal to approximately 250000 cells. The left-hand upper quadrant shows the cows with a new infection. Cows with new infections, where high SCC remain in subsequent samples should be sampled for evaluation of bacteriological status (now in the upper right-hand quarter of Fig. 11). Observation of milking procedures, scoring of teat-end quality, scoring of cow and udder hygiene, scoring of cubicle hygiene, evaluation of separation of chronically infected animals and evaluation of the cow environment are key risk factors that affect the new infection rate.

In Figure 12, the new infections are plotted against days in milk. In this herd there is a high rate of new infections in the first 100 days of lactation. This was also observed for the clinical mastitis cases (Fig. 10). This points towards management procedures in the dry period, transition period or with the early fresh cows that lead to high infection risks. These risk factors should evaluated in much more detail when data such as shown in this herd example are observed.

\subsubsection{Cure}

Monitoring of success of treated animals can be done using culturing of treated animals, or by following cell count patterns of animals that have been treated. An example of this is monitoring of dry cow 


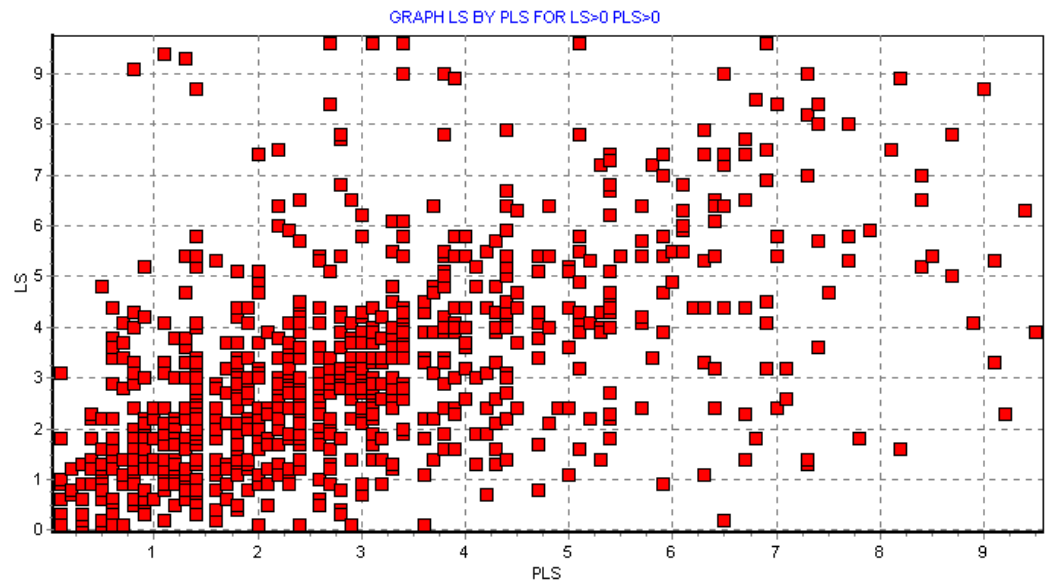

Figure 11. Graph of previous test day linear score (PLS) versus last test day linear score (LS).

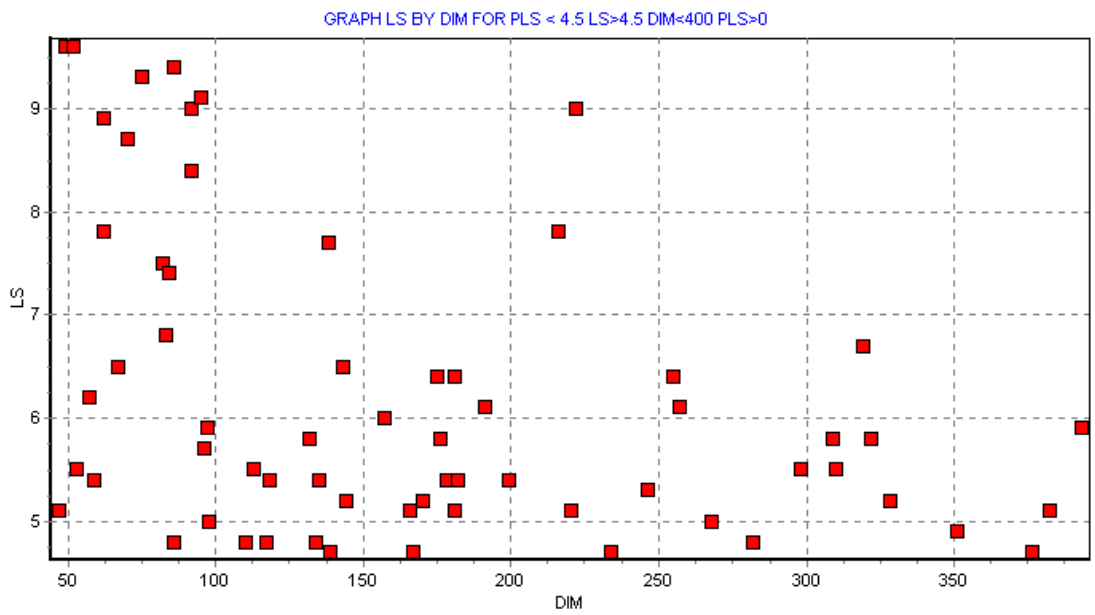

Figure 12. Occurrence of new infections (defined as a cow with a previous LS $<4.5$ and next LS $>$ 4.5) graphed against days in milk (DIM) at occurrence of new infection.

treatment by graphing of cell counts at dryoff versus cell counts at calving. Usually at least $80 \%$ of cows with high cell count at dry-off should be low at calving. A similar analysis of cell count data can be used to evaluate treatments during lactation. Cows with high cell count at previous test day that were treated in lactation should have at least a 50\% chance of having a low cell count at current test day. Monitoring of susceptibility patterns of bacteria isolated from clinical and subclinical infections is important to observe whether current treatment protocols are adequate. Monitoring 
Table II. List of cows with a recent case of mastitis and their subsequent udder health performance. All dates are in $\mathrm{mm} / \mathrm{dd} / \mathrm{yy}$ style.

\begin{tabular}{lcccccccccc}
\hline CowID $^{\mathrm{a}}$ & DIM & Lact & FreshDat & MastDat & Remark & PrevTdat & Tdat & PLS & LS & Nmast \\
\hline 1678 & 235 & 2 & $6 / 30 / 00$ & $12 / 13 / 00$ & RFPIRSUE & $1 / 11 / 01$ & $2 / 12 / 01$ & 5.8 & 7.2 & 2 \\
2957 & 69 & 1 & $12 / 13 / 00$ & $12 / 13 / 00$ & RHAC & $1 / 11 / 01$ & $2 / 12 / 01$ & 2.6 & 0.5 & 1 \\
530 & 251 & 5 & $6 / 14 / 00$ & $12 / 15 / 00$ & RHAC & $1 / 11 / 01$ & $2 / 12 / 01$ & 5.7 & 4.1 & 1 \\
1338 & 81 & 4 & $12 / 1 / 00$ & $12 / 18 / 00$ & LFPIRSUE & $1 / 11 / 01$ & $2 / 12 / 01$ & 5.1 & 3.2 & 1 \\
2067 & 196 & 2 & $8 / 8 / 00$ & $12 / 18 / 00$ & RHPIRSUE & $1 / 11 / 01$ & $2 / 12 / 01$ & 7.4 & 3.6 & 1 \\
2629 & 71 & 1 & $12 / 11 / 00$ & $12 / 18 / 00$ & LHAC & $1 / 11 / 01$ & $2 / 12 / 01$ & 2.7 & 0.9 & 2 \\
2926 & 64 & 1 & $12 / 18 / 00$ & $12 / 19 / 00$ & RHPIRSUE & $1 / 11 / 01$ & $2 / 12 / 01$ & 5.0 & 2.4 & 1 \\
1528 & 277 & 3 & $5 / 19 / 00$ & $12 / 20 / 00$ & LHAC & $1 / 11 / 01$ & $2 / 12 / 01$ & 8.5 & 5.4 & 1 \\
2114 & 82 & 2 & $11 / 30 / 00$ & $12 / 20 / 00$ & RFPIRSUE & $1 / 11 / 01$ & $2 / 12 / 01$ & 1.7 & 0.6 & 1 \\
1943 & 112 & 2 & $10 / 31 / 00$ & $12 / 23 / 00$ & LHAC & $1 / 11 / 01$ & $2 / 12 / 01$ & 6.9 & 9.6 & 2 \\
2653 & 61 & 1 & $12 / 21 / 00$ & $12 / 23 / 00$ & LHPIRSUE & $1 / 11 / 01$ & $2 / 12 / 01$ & 2.0 & 1.1 & 1 \\
2440 & 56 & 2 & $12 / 26 / 00$ & $12 / 26 / 00$ & RHAC & $1 / 11 / 01$ & $2 / 12 / 01$ & 1.8 & 1.4 & 1 \\
2903 & 59 & 1 & $12 / 23 / 00$ & $12 / 26 / 00$ & RHAC & $1 / 11 / 01$ & $2 / 12 / 01$ & 4.3 & 1.3 & 1 \\
2910 & 59 & 1 & $12 / 23 / 00$ & $12 / 26 / 00$ & LHAC & $1 / 11 / 01$ & $2 / 12 / 01$ & 5.2 & 2.2 & 1 \\
2991 & 57 & 1 & $12 / 25 / 00$ & $12 / 26 / 00$ & POLYIV & $1 / 11 / 01$ & $2 / 12 / 01$ & 2.0 & 2.0 & 1 \\
\hline
\end{tabular}

a CowID: cow number, DIM: current days in milk, Lact: lactation number, FreshDat: date of calving, MastDat: date of mastitis, Remark: treatment remark, PrevTdat, Tdat: previous and last test dates, PLS, LS: previous and last linear score, Nmast: number of mastitis cases in this lactation.

the treatment protocols, the proper use of medications, the quality of storage and maintenance of drug cabinets and the prevention of treatment residues should be evaluated on a regular basis (i.e. annually). In Table II, the recent cases of clinical mastitis are tabulated. Information in this table includes cow number (CowID), current days in milk (DIM), lactation number (Lact), date of calving (FreshDat), date of mastitis (MastDat), treatment remark (Remark), the previous and last test dates (PrevTdat, Tdat), previous and last linear score (PLS, LS) and the number of mastitis cases in this lactation (Nmast). Using the data in Table II, an impression of clinical cure rate per treatment protocol can be obtained. Using linear score after the last clinical case again as a proxy for cure, cow
1678 would be considered a non-cure whereas cow 2957 would be considered a cure.

Another important component here is the evaluation of non-cured or even nontreated animals. These are the long term infected animals, in Figure 11 these are the animals in the upper right hand corner. A number of these animals may be eligible for treatment, especially valuable young animals with a relative short duration of infection should be considered [52, 53].

\subsubsection{Culling}

Monitoring of culling can be done by evaluating the culling data, evaluating the reasons for culling, evaluation the mean 
Table III. List of cows with a high linear score, multiple cases of clinical mastitis, and sorted by their economic value.

\begin{tabular}{lccccccccccc}
\hline CowID $^{\mathrm{a}}$ & Lact & DIM & CwVal & Relv & LS1 & PLS4 & PLS3 & PLS & LS & AVLS & Nmast \\
\hline 1170 & 3 & 566 & -309 & 66 & 6.5 & 5.4 & 3.6 & 3.8 & 5.4 & 6.0 & 5 \\
988 & 4 & 240 & -218 & 98 & 1.8 & 7.5 & 7.5 & 5.4 & 2.7 & 4.8 & 3 \\
1194 & 4 & 189 & -79 & 83 & 9.5 & 7.1 & 6.4 & 7.0 & 8.4 & 7.7 & 4 \\
1678 & 2 & 235 & -70 & 97 & 5.3 & 4.7 & 9.4 & 5.8 & 7.2 & 5.5 & 2 \\
4976 & 5 & 497 & -63 & 87 & 4.9 & 5.5 & 5.8 & 8.1 & 7.5 & 6.3 & 3 \\
1943 & 2 & 112 & -62 & 70 & 0.6 & 0.6 & 0.0 & 6.9 & 9.6 & 5.7 & 2 \\
211 & 6 & 208 & 161 & 84 & 1.6 & 6.4 & 5.2 & 7.3 & 8.2 & 6.4 & 4 \\
5229 & 4 & 397 & 235 & 103 & 6.4 & 6.3 & 6.7 & 9.0 & 8.7 & 5.9 & 2 \\
1959 & 2 & 321 & 322 & 78 & 9.0 & 6.4 & 5.8 & 8.3 & 0.0 & 8.0 & 4 \\
1813 & 2 & 319 & 453 & 90 & 6.0 & 8.7 & 4.3 & 4.4 & 6.7 & 5.9 & 2 \\
669 & 4 & 433 & 624 & 105 & 0.4 & 3.4 & 3.9 & 4.1 & 0.0 & 5.0 & 2 \\
5436 & 1 & 270 & 729 & 91 & 8.3 & 3.4 & 2.7 & 3.8 & 2.9 & 4.7 & 2 \\
2584 & 1 & 212 & 839 & 95 & 5.8 & 4.4 & 6.4 & 6.5 & 7.4 & 5.7 & 2 \\
1696 & 3 & 109 & 1023 & 113 & 4.1 & 4.1 & 4.4 & 7.4 & 8.4 & 6.0 & 2 \\
2622 & 1 & 191 & 1131 & 105 & 6.2 & 9.1 & 8.4 & 9.4 & 6.3 & 7.9 & 2 \\
2513 & 1 & 248 & 1217 & 109 & 7.4 & 2.3 & 7.7 & 1.9 & 2.8 & 4.7 & 3 \\
\hline
\end{tabular}

a CowID: cow number, Lact: lactation number, DIM: current days in milk, CwVal: economic value of this cow in US \$ compared to a replacement heifer, Relv: relative production level compared to the average cow in the herd, LS1: linear score after calving, PLS4, PLS3, PLS, LS: last four linear scores, AVLS: average linear score up until the last test date, Nmast: number of mastitis cases in this lactation.

SCC and the number of clinical events of culled animals are useful tools to monitor the udder health impact on culling. Probably a more important part of monitoring is the evaluation of cows that have not been culled and should have been placed on the culling list. A list of cows in the herd sorted by the number of mastitis cases and also by the length of high SCC in the current and previous lactation is a tool for analyzing the presence of animals that should have been considered for culling. An example of such a list is shown in Table III. Information in this table includes cow number (CowID), lactation number (Lact), current days in milk (DIM), economic value of this cows compared to a replacement heifer $(\mathrm{CwVal})$, relative production level compared to the average cow in the herd (Relv), linear score after calving (LS1), the last four linear scores (PLS4, PLS3, PLS, LS), average linear score up until the last test date (AVLS) and the number of mastitis cases in this lactation (Nmast). Cow 1194 has a negative economic value ( $\mathrm{CwVal}-79)$, low relative value, long term high LS and 4 cases of clinical mastitis. This cow should be considered for culling. Failure to cull such cows may lead to further transmission of contagious mastitis in the herd. 


\section{CONCLUSION}

Somatic cell counts are a valuable component of monitoring programs. Somatic cell count measure the inflammatory response to an IMI. We have shown that with some care SCC can be used as a proxy for measuring IMI and milk quality at cow, herd and population level. In this review we have argued that udder health is more than low somatic cell counts. It also includes low incidence of clinical mastitis, minimize potential hazards for human health such as prevention of residues in milk, potential transfer of antibiotic resistance to human pathogens, and transfer of pathogens through dairy products. Addressing consumer demands with regard to product safety, transmission of infectious diseases, welfare and eco-system health [56] becomes a constraint on the dairy production systems. It is therefore inevitable that more complete udder health programs and monitoring systems have been developed and implemented.

Udder health monitoring is an essential component of preventive veterinary medicine. Preventive programs that address all important udder health components are necessarily complex and dynamic. These programs will need to include components of the standard mastitis prevention plan (milking technique and milking machine performance, post-milking teat disinfection, culling policy for chronically infected animals, antibiotic treatment at dry-off and clinical events) [32], but additionally address hygiene, nutrition, housing and cow comfort, air and water quality, antibiotic use, health monitoring, breeding policy, and cow characteristics such as immunologic competence, cow conformation (teat and udder) and milk production level [21, 41, 48, 61]. In each of these categories, a number of critical issues should be defined, and included into a comprehensive control scheme. Recently, a number of control programs aimed at all udder health issues have been designed $[9,16]$. The efficacy of such programs to optimize all udder health issues has not been shown yet. It may be expected that compliance to actively participate will not be high unless monetary incentives and/or production restrictions are a component of such udder health programs [46]. These programs are dynamic and complex. Implementation of complete udder health programs should be accompanied by research efforts to further fine-tune these complete udder health control and monitoring programs.

\section{ACKNOWLEDGEMENTS}

The authors would like to express their gratitude for the constructive comments of the two anonymous reviewers. Figures 9, 10, 11, and 12 were made using the software program DairyComp 305.

\section{REFERENCES}

[1] Barkema H.W., Schukken Y.H., Lam T.J.G.M., Incidence of clinical mastitis in dairy herds grouped in three categories by bulk milk somatic cell counts, J. Dairy Sci. 81 (1998) 411-419.

[2] Barkema H.W., Schukken Y.H., Lam T.J.G.M., Management practices associated with low, mid, and high bulk milk somatic cell count, J. Dairy Sci. 81 (1998) 19171927.

[3] Beaudeau F., Fourichon C., Seegers H., Bareille N., Risk of clinical mastitis in dairy herds with a high proportion of low individual milk somatic-cell counts, Prev. Vet. Med. 53 (2002) 43-54.

[4] Becker N.G., Analysis of infectious disease data, Chapman and Hall, London, 1989.

[5] Booth J.M., Mastitis cell count data, IDF mastitis news 134 (1993) 2-8.

[6] Bradley A.J., Green M.J., Mastitis monitoring, Vet. Rec. 144 (1999) 484.

[7] Bradley A.J., Green M.J., Adaptation of Escherichia coli to the bovine mammary gland, J. Clin. Microbiol. 39 (2001) 18451849.

[8] Burvenich C., Paape M.J., Hill A.W., Guidry A.J., Miller R.H., Heyneman R., Kremer 
W.D.J., Brand A., Role of the neutrophil leucocyte in the local and systemic reactions during experimentally induced $E$. coli mastitis in cows immediately after calving, Vet. Q. 16 (1994) 45-50.

[9] Cullor J.S., HACCP: is it coming to the dairy, J. Dairy Sci. 80 (1997) 3449-3452.

[10] Djabri B., Bareille N., Beaudeau F., Seegers H., Quarter milk somatic cell count in infected dairy cows: a meta-analysis, Vet. Res. 33 (2002) 335-357.

[11] Dohoo I.R., Leslie K.E., Evaluation of changes in somatic cell counts as indicators of new intramammary infections, Prev. Vet. Med. 10 (1991) 225-237.

[12] Döpfer D.D., Recurrent Clinical Escherichia coli mastitis in dairy cows, Ph.D. thesis, University of Utrecht, the Netherlands, 2000.

[13] Elbers A.R.W., Miltenburg J.D., DeLang D., Risk factors for clinical mastitis in a random sample of dairy herds from the southern part of the Netherlands, J. Dairy Sci. 81 (1998) $420-426$.

[14] Erskine R.J., Eberhart R.J., Hutchinson L.J., Spencer S.B., Cambell M.A., Herd management and prevalence of mastitis in dairy herds with high and low somatic cell counts, JAVMA 190 (1987) 1411-1416.

[15] Faye B., Lescourret F., Dorr N., Interrelationships between herd management practices and udder health status using canonical correspondence analysis, Prev. Vet. Med. 32 (1997) 171-192.

[16] Godkin A., Monitoring and controlling mastitis: progress in Ontario, Proc. Natl. Mastitis Council Ann. Mtg, Feb. 14-17, 1999, Arlington, VA, USA, 1999, pp. 1-9.

[17] Green M., Green L., Cripps P., Low bulk milk SCC and toxic mastitis, Vet. Rec. 138 (1996) 452.

[18] Harmon R.J., Physiology of mastitis and factors affecting somatic cell counts, J. Dairy Sci. 77 (1994) 2103-2112.

[19] Hayes M.C., Ralyea R.D., Murphy S.C., Carey N.R., Scarlett J.M., Boor K.J., Identification and characterization of elevated microbial counts in bulk tank raw milk, J. Dairy Sci. 84 (2001) 292-298.

[20] Hogan J.S., Hoblet K.H., Smith K.L., Todhunter D.A., Schoenberger P.S., Hueston W.E., Pritchard D.E., Bowman G.L., Heider L.E., Brockette B.L., Conrad H.R., Bacterial and somatic cell counts in bulk tank milk from nine well managed herds, J. Food Prot. 51 (1988) 930-934.

[21] Hogan J.S., Smith K.L., Hoblet K.H., Field survey of clinical mastitis in low somatic cell count herds, J. Dairy Sci. 72 (1989) 15471556.

[22] Honkanen-Buzalski T., Myllys V., Mastitis prevention has succeeded in Finland, IDF Mastitis News 144 (1996) 20-22.

[23] Kelly A.L., Tiernan D., O'Sullivan C., Joyce P., Correlation between bovine milk somatic cell count and polymorphonuclear leukocyte level for samples of bulk milk and milk from individual cows, J. Dairy Sci. 83 (2000) 300304.

[24] Laevens H., Deluyker H., Schukken Y.H., De Meulemeester L., Vandermeersch R., De Muelenaere E., De Kruif A., Influence of parity and stage of lactation on the somatic cell count in bacteriologically negative dairy cows, J. Dairy Sci. 80 (1997) 3219-3226.

[25] Lam T.J.G.M., Dynamics of Bovine mastitis, Ph.D. thesis, Utrecht University, 1996.

[26] Lam T.J.G.M., VanVliet J., Schukken Y.H., The effect of discontinuation of postmilking teat disinfection in low somatic cell counts herds: Dynamics of intra mammary infections, Vet. Quart. 19 (1997) 47-53.

[27] Leslie K.E., Schukken Y.H., Sargeant J., Mitchell M., Inhibitor violations during 10 years in Ontario. Association with Somatic Cell Count reduction program. Report to the Ontario Buro of Veterinary drugs, 1997.

[28] McDermott M.P., Erb H.N., Natzke R.P., Predictability by somatic cell counts related to prevalence of intrammary infection within herds, J. Dairy Sci. 65 (1982) 1535-1539.

[29] Miltenburg J.D., DeLange D., Crauwels A.P.P., Incidence of clinical mastitis in a random sample of dairy herds in the southern Netherlands, Vet. Rec. 139 (1996) 204-207.

[30] Myllys V., Honkanen-Buzalski T., Huovinen P., Sandholm M., Nurmi E., Association of changes in the bacterial ecology of bovine mastitis with changes in the use of milking machines and antibacterial drugs, Acta Vet. Scand. 35 (1994) 363-369.

[31] Myllys V., Asplund K., Brofeldt E., HirvelaKoski V., Honkanen-Buzalski T., Junttila J., Kulkas L., Myllykangas O., Niskanen M., Saloniemi H., Sandholm M., Saranpaa T., Bovine mastitis in Finland in 1988 and 1995changes in prevalence and antimicrobial resistance, Acta. Vet. Scand. 39 (1998) 119126. 
[32] Neave F.K., Dodd F.H., Kingwill R.G., Westgarth D.R., Control of mastitis in the dairy herd by hygiene and management, $\mathrm{J}$. Dairy Sci. 52 (1969) 696-707.

[33] Oliver S.P., Mitchell B.A., Prevalence of mastitis pathogens in herds participating in a mastitis control program, J. Dairy Sci. 67 (1984) 2436-2440.

[34] Østerås O., Mastitis Dynamics and Prevention, Proc. Nordic Seminar on Mastitis Prevention, Denmark, 1998, pp. 5-10.

[35] Ott S.L., Smith M. A., Bulk tank somatic cell counts of milk in 21 states, Proc. Natl. Mastitis Council Ann. Mtg, Feb. 25-28, 2000, St. Louis, MO, USA, pp. 151-152.

[36] Peeler E.J., Green M.J., Fitzpatrick J.L., Morgan K.L., Green L.E., Risk factors associated with clinical mastitis in low somatic cell count dairy herds, J. Dairy Sci. 83 (2000) 2464 2472 .

[37] Peeler E.J., Green M.J., Fitzpatrick J.L., Green L.E., The association between individual quarter, cow and bulk milk somatic cell counts, Ph.D. thesis, University of Bristol, Bristol, UK, 2001.

[38] Pillai S.R., Kunze E., Sordillo L.M., Jayarao B.M., Application of differential inflammatory cell count as a tool to monitor udder health, J. Dairy Sci. 84 (2001) 1413-1420.

[39] Plym Forshell K., Milk quality and mastitis control in Sweden, Proc. Natl. Mastitis Council, 1996, pp. 42-49.

[40] Plym Forshell K., Osteras O., Aagaard K., Kulkas L., Antimicrobial drug policy in four nordic countries, IDF Mastitis News 144 (1996) 26-28.

[41] Reneau J.K., Schukken Y.H., Wilson D.J., Barkema H.W., Somatic cell counts: measures of farm management and milk quality, Proc. National Mastitis Council, Regional Meeting, Syracuse, New York, 2002, pp. $1-10$

[42] Ruegg P.L., Rheineman D., Milk quality and mastitis tests, Bovine Practitioner 36 (2002) 41-54.

[43] Ruegg P.L., Tabone T.J., The relationship between antibiotic residue violations and somatic cell counts in Wisconsin dairy herds, J. Dairy Sci. 83 (2000) 2805-2809.

[44] Rupp R., Beaudeau R., Boichard D., Relationship between milk somatic cell counts in the first lactation and clinical mastitis occurrence in the second lactation of French Holstein cows, Prev. Vet. Med. 46 (2000) 99-111.
[45] Sargeant J.M., Schukken Y.H., Leslie K.E., Ontario bulk milk somatic cell count reduction program: progress and outlook, J. Dairy Sci. 81 (1998) 1545-1554.

[46] Sargeant J.M., Leslie K.E., Shirley J.E., Pulkrabek B.J., Lim G.H., Sensitivity and specificity of somatic cell count and California Mastitis Test for identifying intramammary infection in early lactation, J. Dairy Sci. 84 (2001) 2018-2024.

[47] Schepers A.J., Lam T.J., Schukken Y.H., Wilmink J.B., Hanekamp W.J., Estimation of variance components for somatic cell counts to determine thresholds for uninfected quarters, J. Dairy Sci. 80 (1997) 1833-1840.

[48] Schukken Y.H., Grommers F.J., VanderGeer D., Erb H.N., Brand A., Risk factors for clinical mastitis in herds with a low bulk milk somatic cell count. I. The data and risk factors for all cases, J. Dairy Sci. 73 (1990) 34633471 .

[49] Schukken Y.H., Leslie K.E., Weersink A.J., Martin S.W., Ontario bulk milk somatic cell count reduction program. I. Impact on somatic cell counts and milk quality, J. Dairy Sci. 75 (1992) 3352-3358.

[50] Shook G.E., Genetic improvement of mastitis through selection on somatic cell count, Vet. Clinics of North America: Food Animal Practice 9 (1993) 563-581

[51] Shuster D.E., Kehrli M.E., Baumrucker C.R., Relationship of inflammatory cytokines, growth hormone and insulin-like growth factor-1 to reduced performance during infectious disease, Proc. Soc. Exp. Biol. Med. 210 (1995) 140-149.

[52] Sol J., Cure of Staphylococcus aureus mastitis in Dutch dairy cows, Ph.D. thesis, University of Utrecht, The Netherlands, 2002.

[53] Sol J., Sampimon O.C., Snoep J.J., Schukken Y.H., Factors associated with bacteriological cure after dry cow treatment of subclinical staphylococcal mastitis with antibiotics, J Dairy Sci. 77 (1994) 75-79.

[54] Sordillo L.M., Shafer-Weaver K., DeRosa D., Immunobiology of the mammary gland, J. Dairy Sci. 80 (1997) 1851-1865.

[55] Suriyasathaporn W., Schukken Y. H., Nielen M., Brand A., Low somatic cell count: a risk factor for subsequent clinical mastitis in a dairy herd, J. Dairy Sci. 83 (2000) 1248.

[56] Vaarst M., Enevoldsen C., Patterns of clinical mastitis manifestations in Danish organic herds, J. Dairy Res. 64 (1997) 23-37. 
[57] van Schaik G., Lotem M., Schukken Y.H., Trends in somatic cell counts, bacterial counts, and antibiotic residue violations in New York State during 1999-2000, J. Dairy Sci. 85 (2002) 782-789.

[58] Van Werven T., Noordhuizen-Stassen E.N., Daemen A.J., Schukken Y.H., Brand A., Burvenich C., Preinfection in vitro chemotaxis, phagocytosis, oxidative burst, and expression of CD11/CD18 receptors and their predictive capacity on the outcome of mastitis induced in dairy cows with Escherichia coli, J. Dairy Sci. 80 (1997) 67-74.
[59] Wheeler D.J., Chambers D.S., Understanding Statistical Process Control, 2nd Ed., SPC Press, Knoxville, TN, USA, 1992, pp. 12-20.

[60] WHO. The medical impact of the use of antimicrobials in food animals. Report of a WHO meeting, 13-17 October, Berlin, Germany. World Health Organization, Geneva, Switzerland, 1997.

[61] Wilson D.J., Das H.H., Gonzalez R.N., Sears P.M., Association between management practices, dairy herd characteristics, and somatic cell count of bulk tank milk, J. Am. Vet. Med. Assoc. 210 (1997) 1499-1502. 